\title{
Epidemiología del Colecho y de Caminar de Noche a los 12 Meses en una Cohorte de Recién Nacidos
}

\author{
INÁ S. SANTOS ${ }^{1}$; DENISE M. MOTA ${ }^{2}$; ALICIA MATIJASEVICH ${ }^{3}$ \\ 1. Professora titular, Programa de Pós-Graduação em Epidemiologia, Universidade Federal de Pelotas (UFPel), Pelotas, RS, \\ Brazil. \\ 2. Mestre, UFPel, Pelotas, RS, Brazil. \\ 3. Pesquisadora, Programa de Pós-Graduação em Epidemiologia, UFPel, Pelotas, RS, Brazil.
}

\begin{abstract}
Epidemilogy of Co-Sleeping and Nighttime Waking at 12 Months in a Birth Cohort

Objective: To investigate the prevalence and factors associated with co-sleeping and nighttime waking among the children of the Pelotas 2004 cohort at 12 months of age. Methods: All children born in the city of Pelotas, RS, Brazil during 2004 were enrolled on a longitudinal study. Mothers were interviewed at delivery and once more at 12 months of age to obtain information on their sociodemographic and reproductive characteristics and on their children's sleep and the environment in which their children sleep. Co-sleeping was defined as habitually sharing the bed with another person. Multivariate analysis was performed using Poisson regression. Results: The prevalence of co-sleeping at 12 months was 45.8\% (95\%CI 44.2-47.3). Co-sleeping was more common among mothers with low socioeconomic status, less education, younger mothers, mothers with more previous births and among children who wake at night. The prevalence of nighttime waking was $46.1 \%$ (95\% CI 44.6-47.7). Nighttime waking was more common among boys and among the offspring of mothers who had had a greater number of previous pregnancies and of mothers who had been employed while pregnant. Conclusion: Co-sleeping and nighttime waking are common among this study population, indicating a need to continue follow-up in order to observe how long these habits persist through childhood and to investigate their consequences for child development and behavior.

(Key words: Co-sleeping, night time walking, infants).

(Palabras clave: Colecho, caminar de noche, lactantes mayores).

J Pediatr (Rio J). 2008; 84 (2): 114-122
\end{abstract}

ESTE TRABAJO LO PUEDE ENCONTRAR EN EXTENSO EN WWW.SciELO.ORG

Correspondencia a:

Denise Marques Mota

E-mail: denisemmota@gmail.com 